\title{
Chromosomal Diversity of Hoplias malabaricus (Characiformes, Erythrinidae) Along the Magdalena River (Colombia-Northern South America) and Its Significance for the Neotropical Region
}

\author{
Nicole Ibagón, ${ }^{1,2}$ Javier A. Maldonado-Ocampo, ${ }^{3}$ Marcelo de Bello Cioffi, ${ }^{4}$ and Jorge A. Dergam ${ }^{5}$
}

\begin{abstract}
Hoplias malabaricus is one of the most widespread freshwater fish in the Neotropics; all karyotyped populations exhibit diploid numbers ranging from $2 n=39$ to $2 n=42$, with variations that make up to seven karyomorphs, suggesting the existence of a species complex or paraspecies. In this study, we explored the diversity of $H$. malabaricus of the Magdalena River Basin using karyotypic analysis. Cytogenetic analyses were carried out on 32 specimens and six sample sites from the upper, middle, and lower Magdalena River, a trans-Andean basin in Colombia, using standard and molecular techniques and fluorescence in situ hybridization (FISH). The upper and middle Magdalena samples were $2 n=42$ and showed unique fluorescence patterns, whereas the lower Magdalena samples had $2 n=40$, generalized fluorescence patterns, and one specimen with a mosaic karyotype and heteromorphic chromosome pair. The genetic discontinuity along the Magdalena River fits the museum hypothesis, where the $2 n=42 \mathrm{~A}$ predates the modern configuration of the Magdalena Basin in the Late Miocene, and the $2 n=40 \mathrm{C}$ karyomorph represents a more derived condition. Our results underline the complex biogeography of the trans-Andean region, where the Magdalena-Cauca Basin should be considered a freshwater fauna mosaic with divergent evolutionary affinities.
\end{abstract}

Keywords: biogeography, cytogenetics, trahira, trans-Andean, repetitive DNA

\section{Introduction}

$\boldsymbol{H}$ OPLIAS MALABARICUS (Bloch, 1794) occurs from Panama to northern Argentina on both sides of the Andes, ${ }^{1}$ encompassing 41 out of the 52 ecoregions in South America and five ecoregions in Central America. ${ }^{2}$ This erythrinid is considered one of the most complex taxonomic problems in the Neotropical ichthyology. 1,3

Cytogenetic, ${ }^{4-6}$ phylogeographic, ${ }^{7-9}$ and DNA barcoding ${ }^{10-12}$ studies on cis-Andean $H$. malabaricus populations have uncovered high levels of cryptic diversity. Cytogenetic data indicate the existence of seven karyomorphs $(A-G)$ that differ in their diploid numbers, chromosome morphology, and in some cases, several sex chromosome systems ${ }^{4,7,13}$; occasionally, some karyomorphs hybridize. ${ }^{14}$ In the last years, molecular cytogenetic studies have been extensively performed in several $H$. malabaricus karyomorphs. ${ }^{15,16}$

All evidence indicates $H$. malabaricus is a species complex ${ }^{4}$ or paraspecies (sensu Albert et al. ${ }^{17}$ ) due to the existence of several molecular independent lineages and karyomorphs, some of them occurring in sympatry. ${ }^{4,9,12}$ Due to its low vagility, this taxon represents an excellent model for the study of allopatric, ${ }^{18}$ parapatric, and sympatric ${ }^{19}$ conditions, biogeographical analyses, ${ }^{9}$ and studies focusing on survival strategies.

The Neotropical freshwater fish fauna is unique, because it is the largest in the world, and most of its diversity is at low-level taxic differentiation. ${ }^{20}$ Since the late Cretaceous and during the Cenozoic, the Andes orogeny determined the evolution and diversification of Neotropical fish. ${ }^{21,22}$ The Andes uprising and

\footnotetext{
${ }^{1}$ Departamento de Biologia Geral, Universidad Federal de Viçosa, Viçosa, Minas Gerais, Brazil.

${ }^{2}$ Programa de Ecología, Fundación Universitaria de Popayán, Popayán, Cauca, Colombia.

${ }^{3}$ Laboratorio de Ictiologia, Unidad de Ecología y Sistemática (UNESIS), Departamento de Biología, Facultad de Ciencias, Pontificia Universidad Javeriana, Bogotá, Colombia.

${ }^{4}$ Departamento de Genética e Evolução, Universidade Federal de São Carlos, São Carlos, Brazil.

${ }^{5}$ Departamento de Biologia Animal, Universidad Federal de Viçosa, Viçosa, Minas Gerais, Brazil.
} 
the foreland basin caused drastic ecological transformations in the local fish fauna, determining the extinction of fish that characterized older drainage systems. ${ }^{21}$ In each drainage, the faunal composition is a result of extinction, speciation, vicariance, and dispersal. ${ }^{23}$

In Northern South America (NSA), the Magdalena-Cauca River Basin is the largest trans-Andean basin with $1612 \mathrm{~km}$ and a minimum age of $\sim 10 \mathrm{Ma}$ due to the final uplift of the Eastern Cordillera. ${ }^{21}$ The maximum elevation of this basin is of $3685 \mathrm{~m}$ above the sea level. ${ }^{24}$ It harbors 222 fish species, which represent roughly $15 \%$ of the Colombian ichthyofauna. ${ }^{25}$ Such richness is considerably lower than what is observed in other geographically close drainages, such as the Orinoco and the Amazon Basins, which harbor $\sim 1000$ and 2000 fish species, respectively ${ }^{17}$; nonetheless, almost $50 \%$ of the freshwater fish in the Magdalena-Cauca are endemic.

Biodiversity loss is an old trend for the Magdalena-Cauca drainage; paleontological data show that this basin lost at least four species typical of the Amazon and Orinocan region: the lungfish Lepidosiren, Colossoma, Brachyplatystoma, and Arapaima. $^{26,27}$ Therefore, the Magdalena-Cauca Basin is an intriguing scenario for studying the effects of the Andean orogeny and its consequences for speciation, extinction, and immigration of Neotropical freshwater fish.
In Colombia, H. malabaricus occurs in all hydrological basins: Amazon, Orinoco, Magdalena-Cauca, Pacific, and Caribbean $^{25}$; interestingly, this species is absent in the upper Cauca River. ${ }^{28-30}$ According to Rincon-Sandoval et al., $H$. malabaricus exhibits two well-structured lineages, and samples from the Magdalena River Basin form a clade, including Rancheria, Catatumbo, and Tiura Basins. ${ }^{31}$ However, the genetic structure of $H$. malabaricus along the Magdalena Basin is entirely unknown.

Cytogenetic studies on freshwater fish are scanty and restricted to a few endemic species ${ }^{32}$ in Colombia. Here we investigated the cytogenetic diversity of $\mathrm{H}$. malabaricus from the Magdalena River Basin. Our results indicate an apparent parapatric condition, with conspicuous differentiation between upper Magdalena (UM), middle Magdalena (MM) regions, and lower Magdalena (LM), with minor differentiation between the UM and MM regions using conventional and molecular fluorescence in situ hybridization (FISH) techniques.

\section{Materials and Methods}

We carried out cytogenetic analysis on 32 specimens (10 from UM, nine from MM, and 13 from LM; Table 1 and

Table 1. Collection Sites of Hoplias malabaricus from the Magdalena River (Colombia-South America)

\begin{tabular}{|c|c|c|c|}
\hline Code & Collection site & Geographic coordinates & Sex \\
\hline \multicolumn{4}{|c|}{ Upper Magdalena } \\
\hline NI001 & La Boa Creek, Yaguara, Huila, Colombia & $2^{\circ} 43^{\prime} 12.56^{\prime \prime} \mathrm{N} 75^{\circ} 26^{\prime} 8.98^{\prime \prime} \mathrm{W}$ & $\mathrm{F}$ \\
\hline NIO02 & La Boa Creek, Yaguara, Huila & $2^{\circ} 43^{\prime} 12.56^{\prime \prime} \mathrm{N} 75^{\circ} 26^{\prime} 8.98^{\prime \prime} \mathrm{W}$ & $\mathrm{F}$ \\
\hline NI003 & La Boa Creek, Yaguara, Huila, Colombia & $2^{\circ} 43^{\prime} 12.56^{\prime \prime} \mathrm{N} 75^{\circ} 26^{\prime} 8.98^{\prime \prime} \mathrm{W}$ & $\mathrm{M}$ \\
\hline NI004 & Guyubito Creek, Tesalia, Huila, Colombia & $2^{\circ} 33^{\prime} 56.66^{\prime \prime} \mathrm{N} 75^{\circ} 36^{\prime} 40.41^{\prime \prime} \mathrm{W}$ & M \\
\hline NI005 & La Boa Creek, Yaguara, Huila, Colombia & $2^{\circ} 43^{\prime} 12.56^{\prime \prime} \mathrm{N} 75^{\circ} 26^{\prime} 8.98^{\prime \prime} \mathrm{W}$ & $\mathrm{F}$ \\
\hline NI020 & La Arenosa Creek, El Guamo, Tolima, Colombia & $4^{\circ} 13^{\prime} 37.67^{\prime \prime} \mathrm{N} 74^{\circ} 59^{\prime} 31.68^{\prime \prime} \mathrm{W}$ & M \\
\hline NI021 & La Arenosa Creek, El Guamo, Tolima, Colombia & $4^{\circ} 13^{\prime} 37.67^{\prime \prime} \mathrm{N} 74^{\circ} 59^{\prime} 31.68^{\prime \prime} \mathrm{W}$ & M \\
\hline NI022 & La Arenosa Creek, El Guamo, Tolima, Colombia & $4^{\circ} 13^{\prime} 37.67^{\prime \prime} \mathrm{N} 74^{\circ} 59^{\prime} 31.68^{\prime \prime} \mathrm{W}$ & $\mathrm{F}$ \\
\hline NI024 & La Arenosa Creek, El Guamo, Tolima, Colombia & $4^{\circ} 13^{\prime} 37.67^{\prime \prime} \mathrm{N} 74^{\circ} 59^{\prime} 31.68^{\prime \prime} \mathrm{W}$ & M \\
\hline NI025 & La Arenosa Creek, El Guamo, Tolima, Colombia & $4^{\circ} 13^{\prime} 37.67^{\prime \prime} \mathrm{N} 74^{\circ} 59^{\prime} 31.68^{\prime \prime} \mathrm{W}$ & $\mathrm{F}$ \\
\hline \multicolumn{4}{|c|}{ Middle Magdalena } \\
\hline NI027 & La Bernal Creek, Honda, Tolima, Colombia & $5^{\circ} 13^{\prime} 58.33^{\prime \prime} \mathrm{N} 74^{\circ} 43^{\prime} 53.59^{\prime \prime} \mathrm{W}$ & $\mathrm{F}$ \\
\hline NI028 & La Bernal Creek, Honda, Tolima, Colombia & $5^{\circ} 13^{\prime} 58.33^{\prime \prime} \mathrm{N} 74^{\circ} 43^{\prime} 53.59^{\prime \prime} \mathrm{W}$ & $\mathrm{M}$ \\
\hline NI029 & La Bernal Creek, Honda, Tolima, Colombia & $5^{\circ} 13^{\prime} 58.33^{\prime \prime} \mathrm{N} 74^{\circ} 43^{\prime} 53.59^{\prime \prime} \mathrm{W}$ & $\mathrm{F}$ \\
\hline NI030 & La Bernal Creek, Honda, Tolima, Colombia & $5^{\circ} 13^{\prime} 58.33^{\prime \prime} \mathrm{N} 74^{\circ} 43^{\prime} 53.59^{\prime \prime} \mathrm{W}$ & M \\
\hline NI031 & La Bernal Creek, Honda, Tolima, Colombia & $5^{\circ} 13^{\prime} 58.33^{\prime \prime} \mathrm{N} 74^{\circ} 43^{\prime} 53.59^{\prime \prime} \mathrm{W}$ & $\mathrm{F}$ \\
\hline NI032 & La Bernal Creek, Honda, Tolima, Colombia & $5^{\circ} 13^{\prime} 58.33^{\prime \prime} \mathrm{N} 74^{\circ} 43^{\prime} 53.59^{\prime \prime} \mathrm{W}$ & $\mathrm{M}$ \\
\hline NI033 & La Bernal Creek, Honda, Tolima, Colombia & $5^{\circ} 13^{\prime} 58.33^{\prime \prime} \mathrm{N} 74^{\circ} 43^{\prime} 53.59^{\prime \prime} \mathrm{W}$ & $\mathrm{M}$ \\
\hline NI034 & La Bernal Creek, Honda, Tolima, Colombia & $5^{\circ} 13^{\prime} 58.33^{\prime \prime} \mathrm{N} 74^{\circ} 43^{\prime} 53.59^{\prime \prime} \mathrm{W}$ & $\mathrm{F}$ \\
\hline NI035 & La Bernal Creek, Honda, Tolima, Colombia & $5^{\circ} 13^{\prime} 58.33^{\prime \prime} \mathrm{N} 74^{\circ} 43^{\prime} 53.59^{\prime \prime} \mathrm{W}$ & $\mathrm{F}$ \\
\hline \multicolumn{4}{|c|}{ Lower Magdalena } \\
\hline NI039 & La Peña, Cicuco, Bolivar, Colombia & $9^{\circ} 13^{\prime} 37.04^{\prime \prime} \mathrm{N} 74^{\circ} 43^{\prime} 44.74^{\prime \prime} \mathrm{W}$ & M \\
\hline NI040 & Magangue, Bolivar, Colombia & $9^{\circ} 16^{\prime} 28.76^{\prime \prime} \mathrm{N} 74^{\circ} 48^{\prime} 47.85^{\prime \prime} \mathrm{W}$ & M \\
\hline NI041 & Magangue, Bolivar, Colombia & $9^{\circ} 16^{\prime} 28.76^{\prime \prime} \mathrm{N} 74^{\circ} 48^{\prime} 47.85^{\prime \prime} \mathrm{W}$ & M \\
\hline NI042 & Magangue, Bolivar, Colombia & $9^{\circ} 16^{\prime} 28.76^{\prime \prime} \mathrm{N} 74^{\circ} 48^{\prime} 47.85^{\prime \prime} \mathrm{W}$ & M \\
\hline NI043 & Magangue, Bolivar, Colombia & $9^{\circ} 16^{\prime} 28.76^{\prime \prime} \mathrm{N} 74^{\circ} 48^{\prime} 47.85^{\prime \prime} \mathrm{W}$ & M \\
\hline NI044 & Magangue, Bolivar, Colombia & $9^{\circ} 16^{\prime} 28.76^{\prime \prime} \mathrm{N} 74^{\circ} 48^{\prime} 47.85^{\prime \prime} \mathrm{W}$ & $\mathrm{M}$ \\
\hline NI045 & Magangue, Bolivar, Colombia & $9^{\circ} 16^{\prime} 28.76^{\prime \prime} \mathrm{N} 74^{\circ} 48^{\prime} 47.85^{\prime \prime} \mathrm{W}$ & $\mathrm{M}$ \\
\hline NI046 & Magangue, Bolivar, Colombia & $9^{\circ} 16^{\prime} 28.76^{\prime \prime} \mathrm{N} 74^{\circ} 48^{\prime} 47.85^{\prime \prime} \mathrm{W}$ & $\mathrm{M}$ \\
\hline NI047 & La Peña, Cicuco, Bolivar, Colombia & $9^{\circ} 13^{\prime} 37.04^{\prime \prime} \mathrm{N} 74^{\circ} 43^{\prime} 44.74^{\prime \prime} \mathrm{W}$ & $\mathrm{F}$ \\
\hline NI048 & Magangue, Bolivar, Colombia & $9^{\circ} 16^{\prime} 28.76^{\prime \prime} \mathrm{N} 74^{\circ} 48^{\prime} 47.85^{\prime \prime} \mathrm{W}$ & M \\
\hline NI049 & Magangue, Bolivar, Colombia & $9^{\circ} 16^{\prime} 28.76^{\prime \prime} \mathrm{N} 74^{\circ} 48^{\prime} 47.85^{\prime \prime} \mathrm{W}$ & M \\
\hline NI050 & Magangue, Bolivar, Colombia & $9^{\circ} 16^{\prime} 28.76^{\prime \prime} \mathrm{N} 74^{\circ} 48^{\prime} 47.85^{\prime \prime} \mathrm{W}$ & $\mathrm{M}$ \\
\hline NI051 & Magangue, Bolivar, Colombia & $9^{\circ} 16^{\prime} 28.76^{\prime \prime} \mathrm{N} 74^{\circ} 48^{\prime} 47.85^{\prime \prime} \mathrm{W}$ & \\
\hline
\end{tabular}




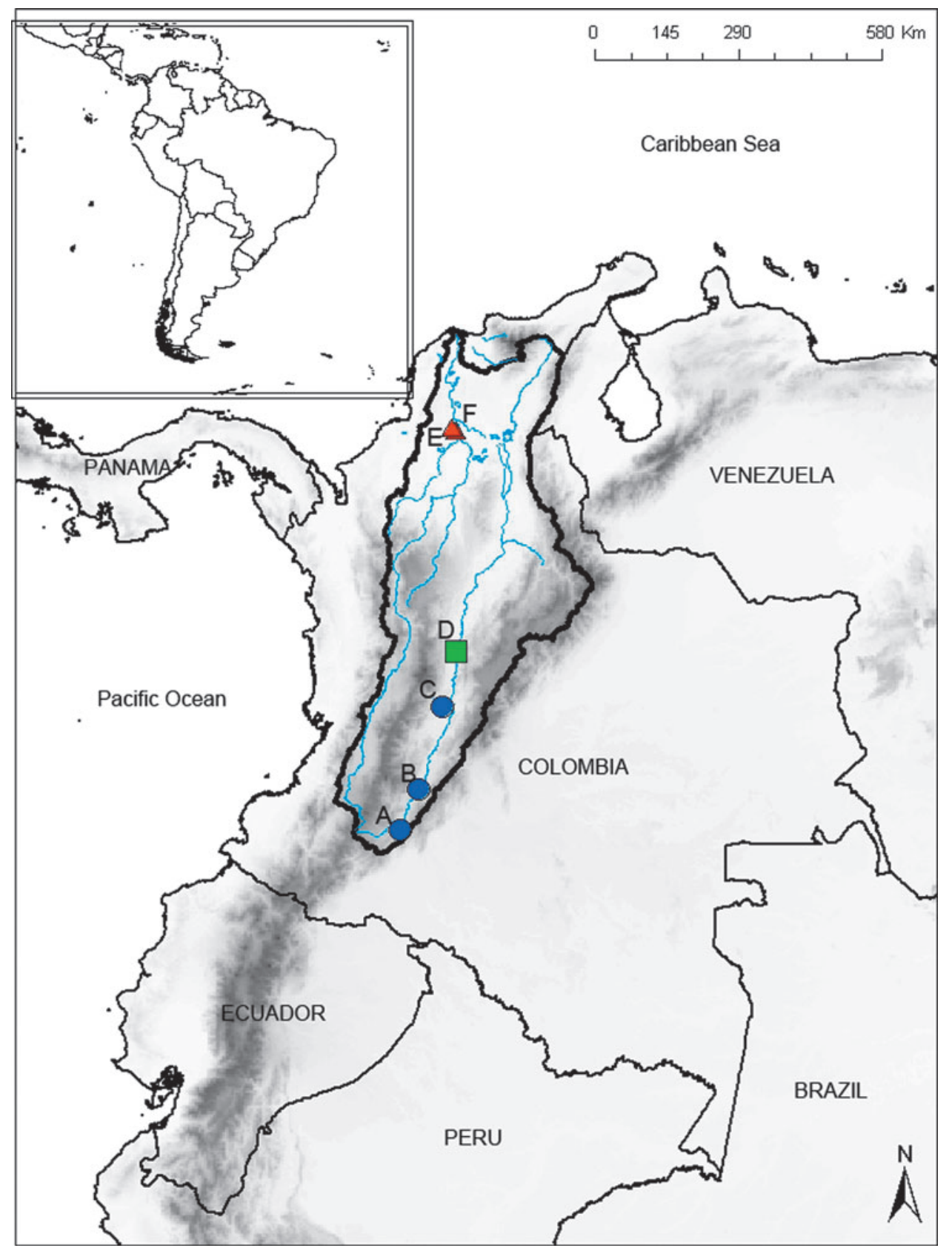

FIG. 1. Collection sites of Hoplias malabaricus from the Magdalena River (surrounded by a dark line). Blue circles show upper Magdalena localities: La Boa Creek, Yaguayá, Huila (A), Guyubito Creek, Tesalia, Huila (B), La Arenosa Creek, El Guamo Tolima (C). Green square shows middle Magdalena: La Bernal Creek, Honda, Tolima (D). Red triangles show lower Magdalena: La Peña, Cicuco, Bolívar (E), Magangue, Bolívar (F). Color images are available online.

Fig. 1.), samples were collected on live specimens and cell division was stimulated with yeast $24 \mathrm{~h}$ before processing ${ }^{33}$; fish were euthanized with clove oil. ${ }^{34}$ Voucher specimens were deposited in the ichthyological collection of the Pontificia Universidad Javeriana in Colombia (MPUJ). Specimen identification followed Oyakawa, ${ }^{1}$ and Oyakawa \& Mattox. ${ }^{35}$

Protocols were carried out according to the Ethics Committee on Animal Use Guidelines (CEUA 29/2013) of the Federal University of Viçosa. Mitotic chromosomes were obtained from anterior kidney cell suspension using the conventional air-drying method. ${ }^{36}$ Chromosomes were stained with Giemsa $0.5 \%$, and images were obtained with an Olympus BX53 microscope using cellSens Dimensions software (Olympus). At least 30 metaphase spreads per individual were analyzed to confirm diploid numbers, kar- yotypic structure, and FISH patterns. Chromosomes were classified as metacentric (m), submetacentric (sm), and acrocentric (a), according to their arm ratios, modified from Levan et al. ${ }^{37}$

FISH included three multigene families isolated from the $H$. malabaricus genome, and some microsatellite motif repeat probes. The first probe was a $5 \mathrm{~S}$ rDNA repeat copy containing 120 base pairs (bp) of the 5S rRNA encoding gene and $200 \mathrm{bp}$ of the nontranscribed spacer (NTS). ${ }^{38}$ The second probe corresponded to a $1400 \mathrm{bp}$ segment of the $18 \mathrm{~S}$ rRNA gene obtained via PCR from nuclear DNA. ${ }^{39}$

The third probe contained a copy of the repetitive satellite 5SHindIII-DNA sequence with 360 bp composed of a $95 \mathrm{bp}$ segment with similarity to the $5 \mathrm{~S}$ rRNA gene of the first probe and a 265 bp segment similar to the NTS of the first probe; the 5SHindIII-DNA is exclusive of $H$. malabaricus. ${ }^{38}$ The 
FIG. 2. Conventionally stained karyomorphs and 5SHindIII-DNA probe of $H$. malabaricus from the upper $(2 n=42 \mathrm{~A})$, middle $(2 n=42 \mathrm{~A})$, and lower Magdalena River $(2 n=40 \mathrm{C})$ in Colombia. Color images are available online.
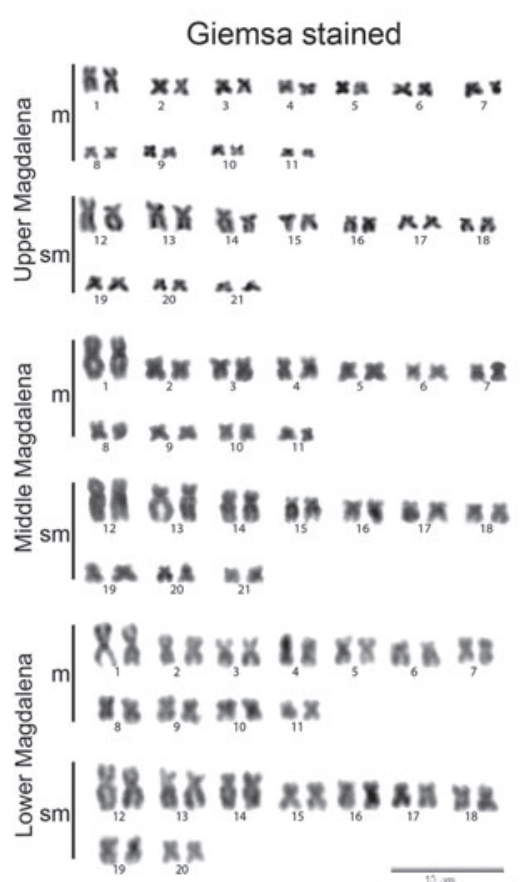

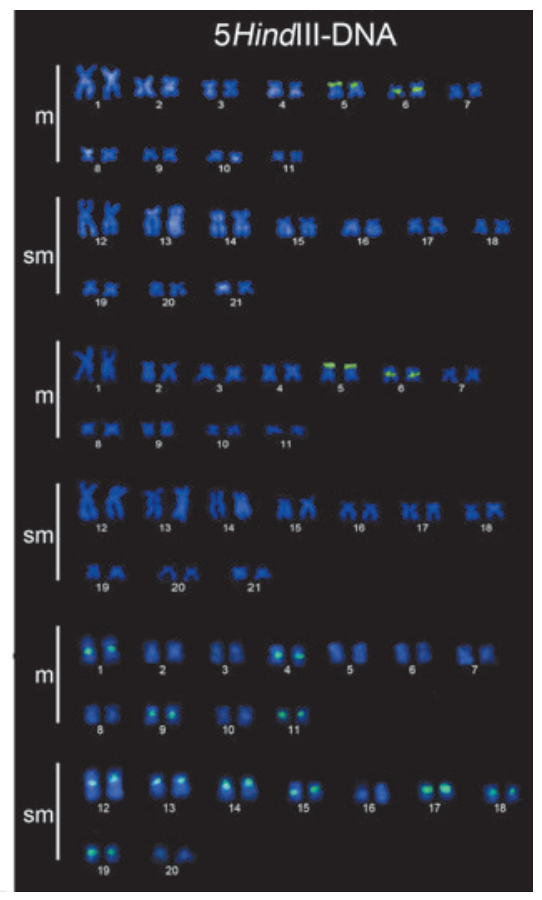

5SHindIII-DNA and 5S rDNA were labeled with Biotin-14dUTP by nick translation (Roche, Basel, Switzerland), while 18S rDNA was labeled with digoxigenin-11-dUTP, also by nick translation (Roche, Basel, Switzerland).

Microsatellite motifs with sequences $(\mathrm{A})_{30},(\mathrm{C})_{30},(\mathrm{CA})_{15}$, $(\mathrm{GA})_{15},(\mathrm{TA})_{15},(\mathrm{CAC})_{10},(\mathrm{CAT})_{10},(\mathrm{GAC})_{10},(\mathrm{GAG})_{10}$, and $(\mathrm{CGG})_{10}$ were synthesized according to Kubat et al. ${ }^{40}$ and commercially labeled with $\mathrm{Cy} 3$ at the $5^{\prime}$ terminus during synthesis (Sigma, St. Louis, MO). All FISH experiments were carried out according to Yano et al. ${ }^{41}$ The 5SHindIIIDNA and 5S rDNA probes were detected with avidin-FITC (Sigma), while the 18S DNA probe was detected with antidigoxigenin/rhodamine (Roche).

We build ideograms for all the karyotypes that had the report of the 5SHindIII-DNA probe in the Neotropical region, including the UM/MM and LM.

\section{Results}

Specimens from the UM and MM showed $2 n=42, \mathrm{FN}=84$, and a karyotype composed of $22 \mathrm{~m}+20 \mathrm{sm}$ with no morphologically differentiated sex chromosomes (Fig. 2). These samples showed 5SHindIII-DNA satellite probes restricted to chromosome pair numbers 5 (in subtelomeric position) and 6 (in pericentromeric position) (Figs. 2 and 3). However, these samples differed in their 5S rDNA probe patterns: they hybridized in the subtelomeric region of chromosome pair number 4 and on the pericentromeric region of chromosome pair number 8, whereas in MM samples, these probes showed pericentromeric markings on chromosome pair number 4 and two very conspicuous subtelomeric and pericentromeric markings on chromosome pair number 17 (Fig. 4).

$18 \mathrm{~S}$ rDNA probes were always subtelomeric and marked some different chromosome pairs in the UM and MM samples: in the UM, these probes occurred on one of the homologues of pair number 21, chromosome pair numbers 12 and 16 , and on one of the homologues of pair number 21 , whereas in MM samples, $18 \mathrm{~S}$ rDNA probes hybridized to both homologues of chromosome pairs 15, 19, and 21 (Fig. 4).

All specimens from LM showed $2 n=40, \mathrm{FN}=80$, and a karyotype composed of $22 \mathrm{~m}+18 \mathrm{sm}$, and no morphologically differentiated sex chromosomes (Fig. 2). In sharp contrast with the UM and MM samples, in the LM, 11 chromosome pairs hybridized with the5SHindIII-DNA probe in their pericentromeric regions (Fig. 2 and 3). Chromosome pair numbers 6 and 10 showed pericentromeric 5S rDNA sites, whereas $18 \mathrm{~S}$ rDNA hybridized on the pericentromeric and telomeric regions of chromosome pair number 4. A syntenic pericentromeric site for both rDNAs was evidenced in pair number 6 (Fig. 4).

Of all the microsatellite DNA probes, only the $(\mathrm{CA})_{15}$ and $(\mathrm{GA})_{15}$ gave consistent results. In all samples, $(\mathrm{CA})_{15}$ probe markings were stronger on larger chromosomes, whereas the $(\mathrm{GA})_{15}$ pattern was more homogeneous among the chromosome pairs. In addition, conspicuous interstitial sites were observed in the largest two submetacentric pairs using both probes (Fig. 5).

In the LM, one male specimen (NI46) showed a heteromorphic chromosome pair, formed by an acrocentric chromosome and a small metacentric and intraindividual variation in chromosome number: $59 \%$ of cells were $2 n=40$, similar to other individuals from the LM (Fig. 6).

In this specimen, the 5SHindIII-DNA probe marked 10 chromosome pairs, besides the acrocentric chromosome and its putative homologue (Fig. 6); the 5S rDNA probe marked three chromosomes, showing a pericentromeric marking on chromosome pair number 17 and an interstitial marking on the acrocentric (Fig. 6). The $18 \mathrm{~S}$ probe hybridized with eight metacentric/submetacentric chromosomes. The $(\mathrm{CA})_{15}$ repetitive DNA probe hybridized with 15 pairs, including the metacentric member of the heteromorphic pair, whereas the $(\mathrm{GA})_{15}$ showed 12 bitelomeric markings in different chromosome pairs and both members of the heteromorphic chromosome pair. 


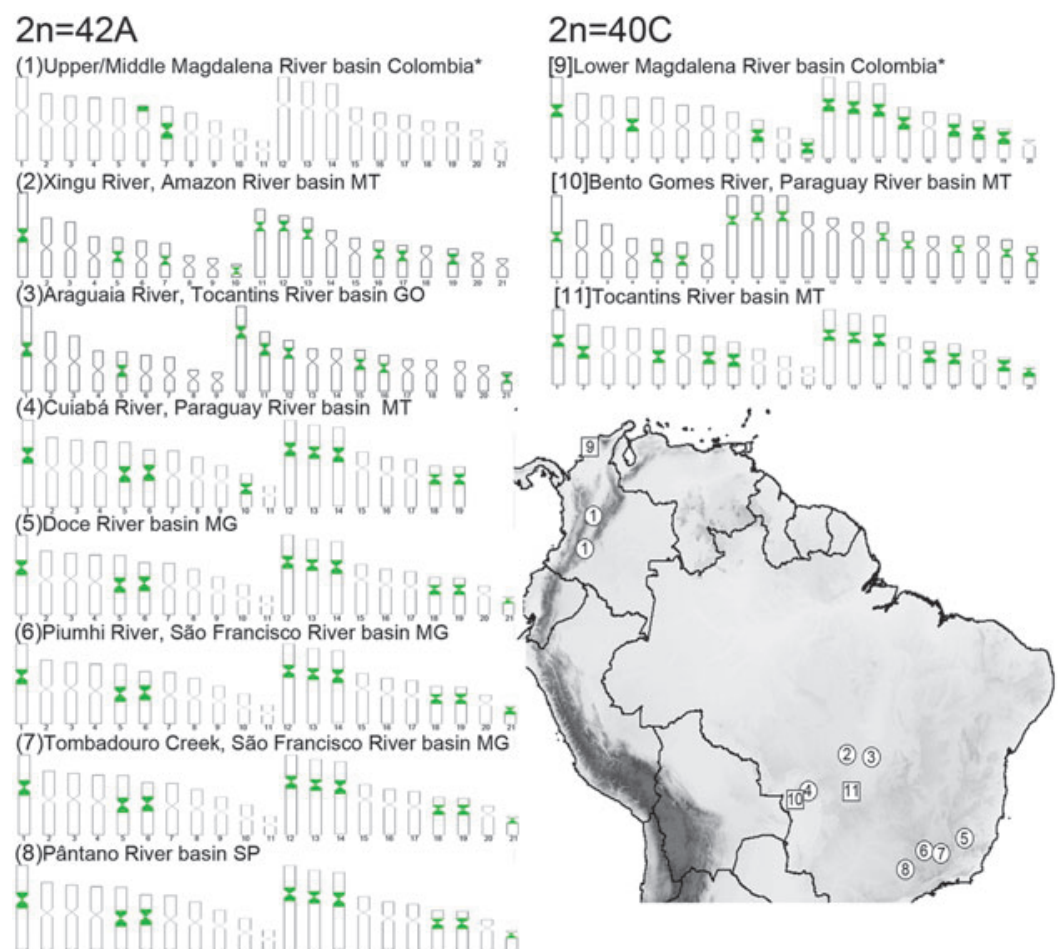

FIG. 3. Geographical variation of 5SHindIII-DNA probe patterns in H. malabaricus. Ideograms 1 and 9 correspond to the present study; 2, 3, and 6 from Blanco et al. ${ }^{18} ; 4,5$, and 8 from Cioffi et al. $2009^{39}$; 7 in Santos et al. ${ }^{7} ; 10$ from Cioffi et al. ${ }^{39}$; and 11 in Vitorino et al. ${ }^{49}$ Circles in the map represent populations with karyomorph $2 n=42 \mathrm{~A}$, squares show karyomorph $2 n=40 \mathrm{C}$ from Bertollo. ${ }^{4}$ Color images are available online.

\section{Discussion}

The paraspecies $H$. malabaricus is one of the cytogenetically most studied taxa in the Neotropics, and this study is the first one conducted in the trans-Andean region. Based on the karyotype classification of Bertollo et al., ${ }^{4}$ the UM/MM karyomorphs were broadly identified as $2 n=42 \mathrm{~A}$, whereas the LM karyomorph was considered a $2 n=40 \mathrm{C}$; the individual with an acrocentric chromosome may represent a new karyomorph or some hybrid form.
Together with $2 n=40 \mathrm{~F}$, both Magdalena karyomorphs are the most widespread in the Brazilian rivers ${ }^{6}$; the $2 n=42 \mathrm{~A}$ karyomorph occurs in the Ctalamochita River (in Argentina) at the southernmost distribution range of this paraspecies. ${ }^{42}$ Da Rosa et al. list all the locations where this paraspecies was cytogenetically studied; $2 n=42 \mathrm{~A}$ and $2 n=40 \mathrm{C}$ occur in 37 and 21 out of 79 locations. In the Amazon Basin, sympatry involving these and other karyomorphs was observed in the Trombetas, Madeira, and Aripuanã Rivers. Sympatry has also been observed in the upper and lower Paraná River, and in southeastern Brazil. ${ }^{6}$

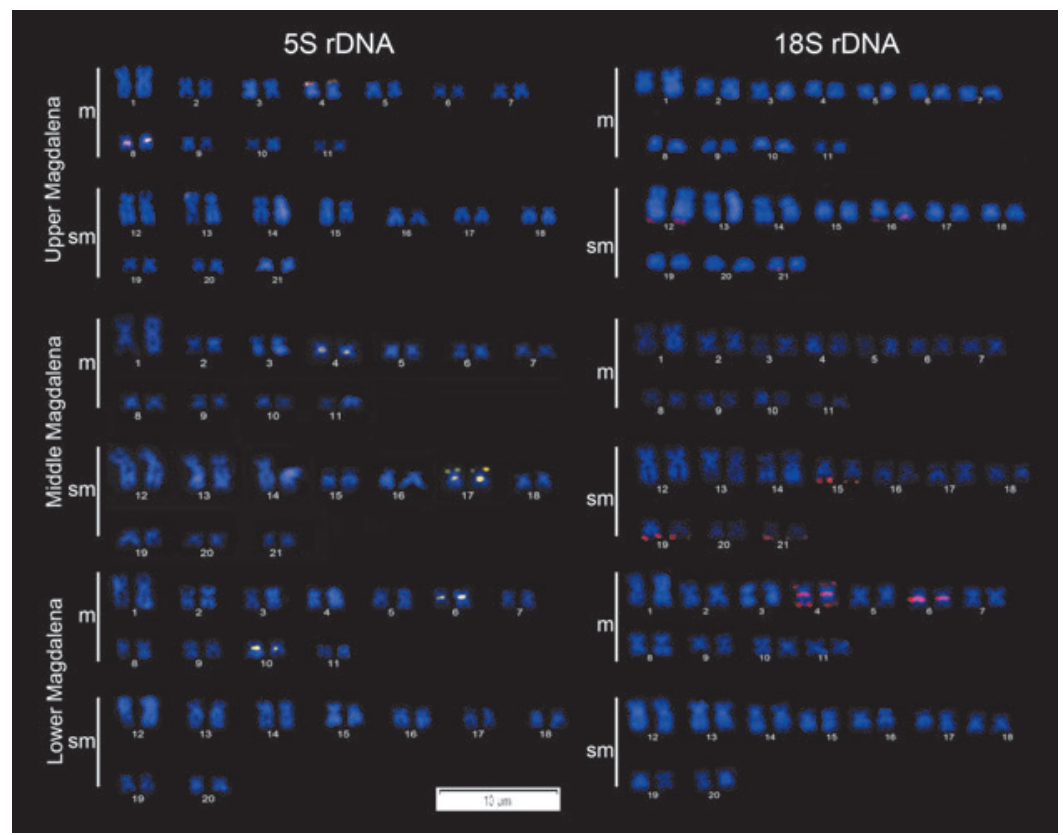

FIG. 4. Karyomorphs with FISH using $5 \mathrm{~S}$ rDNA and $18 \mathrm{~S}$ rDNA probes of H. malabaricus from the upper $(2 n=42 \mathrm{~A})$, middle $(2 n=42 \mathrm{~A})$, and lower Magdalena River $(2 n=40 \mathrm{C})$ in Colombia. FISH, fluorescence in situ hybridization. Color images are available online. 
FIG. 5. Karyomorphs with FISH using repetitive DNA probes (CA) 15 and (GA) 15 of $H$. malabaricus from the upper $(2 n=42 \mathrm{~A})$, middle $(2 n=42 \mathrm{~A})$, and lower Magdalena River $(2 n=40 \mathrm{C})$ in Colombia. Color images are available online.

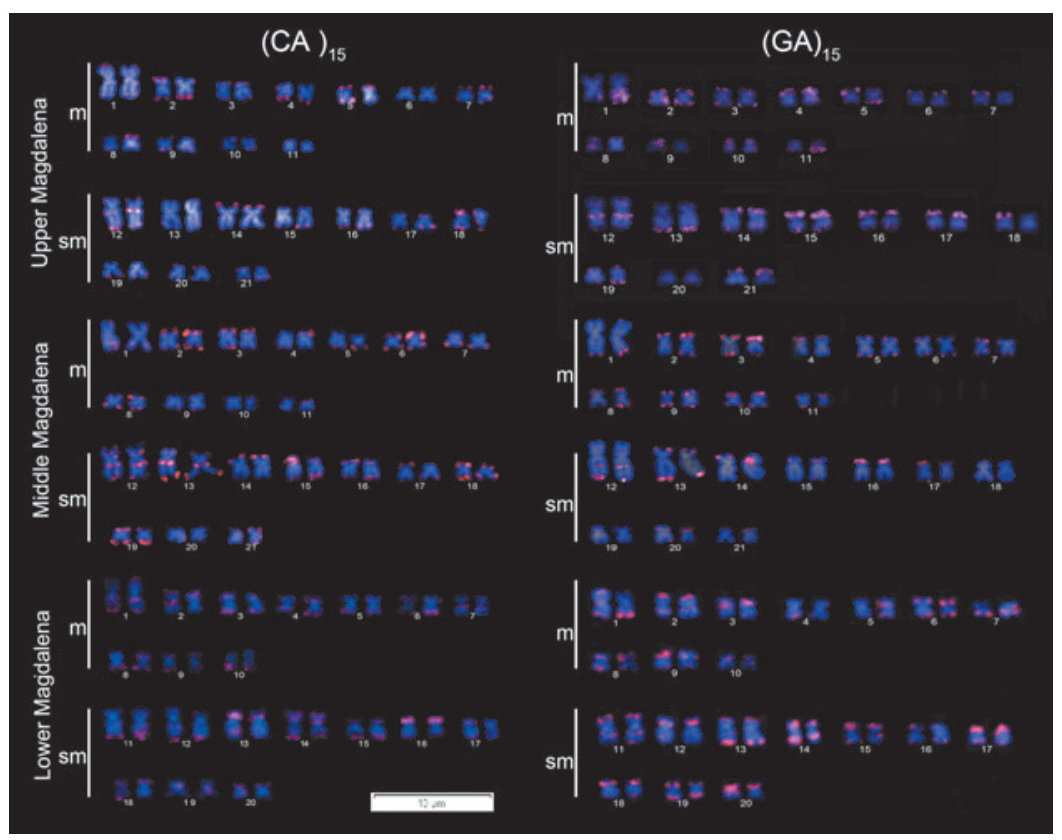

Sympatric or allopatric distribution of karyomorphs in Neotropical basins reflects the geomorphologically dominated hydrology of each drainage: complex evolutionary histories result in sympatric karyomorphs, such as in the Paraná and Amazon Basins, ${ }^{4,43}$ whereas isolated basins are usually characterized by one widespread karyomorph. São Francisco and the Doce River Basins harbor two karyomorphs with allopatric distribution: the widespread $2 n=40 \mathrm{~F}$ occurs along most of its basins, whereas $2 n=42 \mathrm{~A}$ is restricted to two southern tributaries (the Piumhi ${ }^{18}$ and the Pará ${ }^{7}$ Rivers). Another exception is the Doce River Basin, where the widespread $2 n=42 \mathrm{~A}$ karyomorph is syntopic with the $2 n=42 \mathrm{~B}$ karyomorph in two Holocene lakes. ${ }^{8}$

FISH probes also indicated further differentiation among the Magdalena regions. In cis-Andean karyomorphs, the 5SHindIII-DNA probe occurs in a large number of centromeric sites, ranging from 16 to 24 chromosomes in each metaphase, and always involves the largest three submetacentric pairs. $7,13,16,18,38,44$ This general pattern was also observed in the LM. However, the UM and MM were characterized by telomeric and centromeric 5SHindIII-DNA markings on only two chromosome pairs, placing these samples in a unique
FIG. 6. Conventionally stained and FISH of sample NI46 from the lower Magdalena population. Color images are available online.

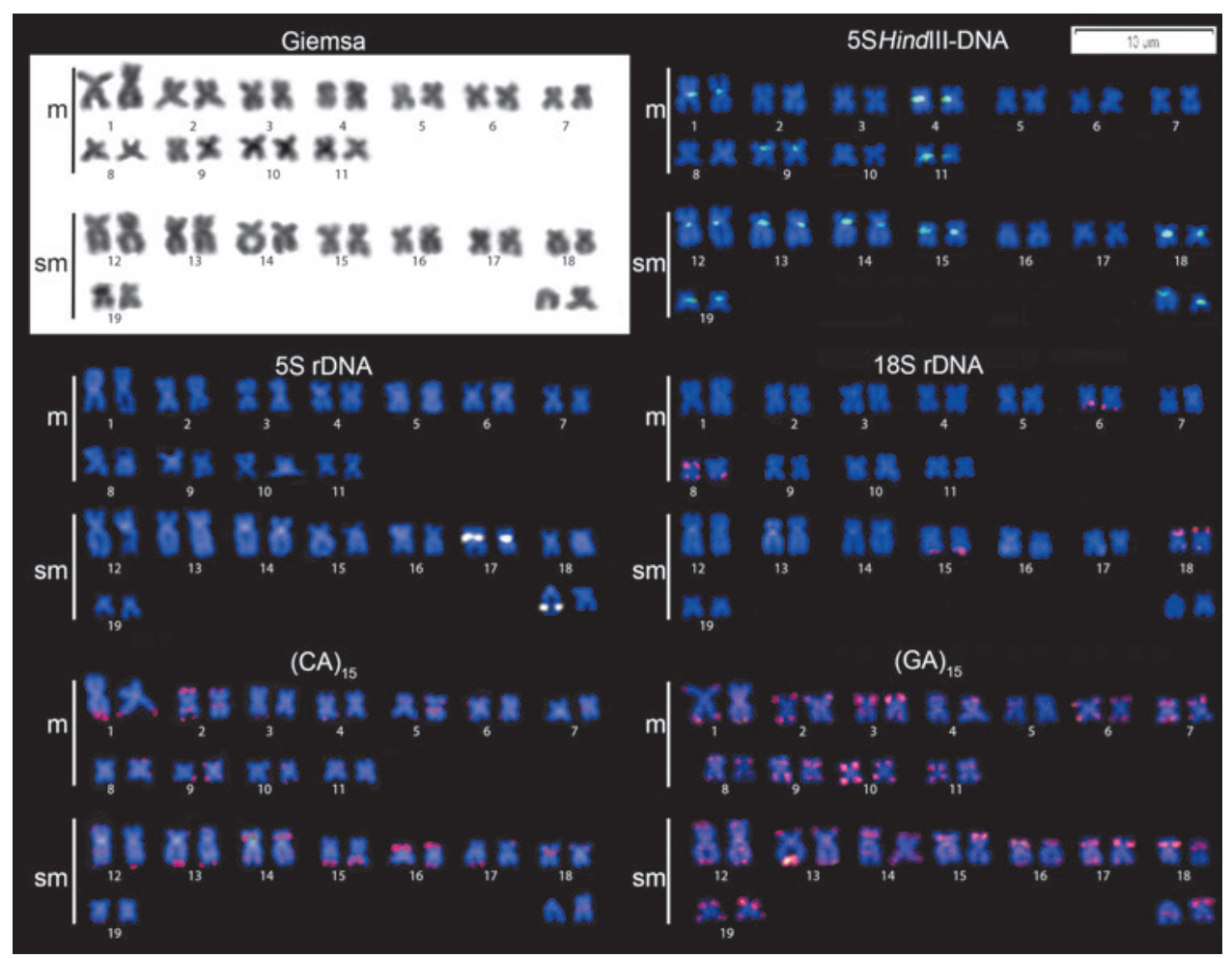


condition among all South American populations (Fig. 3). Studied so far, the evolution of copy number of these sites has been considered a reversible, unordered "loss or gain" character condition during the divergence of $H$. malabaricus. ${ }^{44}$ However, if copy number increases through transposable elements (e.g., Crombach Hogeweg, ${ }^{45}$ ), the multiplication of these copies may be an irreversible process.

Typically, 5S rDNA sites are located in only one or two chromosomal pairs, showing levels of variation within and among karyomorphs from different basins. ${ }^{18,39,44,46,47}$ Likewise, in the Magdalena, the chromosome pairs and probe sites were highly variable among samples. The usefulness of this probe as a populational marker is realized when UM and the MM are compared: in the former, chromosome number 8 showed pericentromeric markings, whereas, in the latter, chromosome pair number 17 showed an additional, telomeric marking. In LM, a syntenic condition for both rDNA clusters was observed. Such an uncommon trait was observed for the first time in a $2 n=42 \mathrm{~A}$ population from the Cuiabá River in Central Brazil, ${ }^{48}$ where it was located in a submetacentric chromosome. Those results from the Magdalena River is the first case where this syntenic condition occurs in a metacentric chromosome and may represent rare independent events within this paraspecies.

Cis-Andean $H$. malabaricus have multiple 18S rDNA markings ranging from 8 to 12 sites, mainly in telomeric regions. ${ }^{18,39}$ In sharp contrast, the UM and MM presented only six subtelomeric 18S rDNA sites. This probe also occurs in bitelomeric position in several $2 n=42 \mathrm{~A}$ Brazilian populations in the Cuiabá, ${ }^{48}$ São Francisco, ${ }^{18}$ and Doce Rivers, ${ }^{48}$ and in one $2 n=40 \mathrm{C}$ in the Araguaia River. ${ }^{49}$ Notably, the LM presented a unique pattern with only two chromosomes bearing these sites, where chromosome number 4 showed both bitelomeric and centromeric sites.

Microsatellites represent one of the most dynamic and widespread components of the genomes. ${ }^{50}$ However, the $(\mathrm{CA})_{15}$ pattern observed in the Magdalena is similar to two other $H$. malabaricus populations from southeastern Brazil, in the coastal Doce $(2 n=42 \mathrm{~B})$, and the upper Paraná $(2 n=40 \mathrm{D})$ Basins, ${ }^{51}$ and therefore, they seem to be very stable within the paraspecies karyotypic evolution. These markers show a conservative pattern also in other Erythrinidae fishes, ${ }^{52,53}$ and in its closely related family Lebiasinidae. ${ }^{54}$ Although Cioffi et al. concluded that this and other repetitive sequences could have some role in the diversification of the family Erythrinidae. ${ }^{51}$ Highly homogeneous marking among chromosome pairs has been observed in many species of Prochilodontidae and Anostomidae (Dergam, unp.).

A mosaic condition involving diploid number and chromosome morphology, observed in the LM NI46 specimen, is an unusual mechanism in fish. Furthermore, acrocentric chromosomes are very rare in $H$. malabaricus, along this paraspecies distribution range: one acrocentric occurs in males of the $G$ karyomorph from the Amazon Basin, these males are $2 n=41$, contrasting with $2 n=40$ females. ${ }^{4}$ The presence of an acrocentric in mosaic condition is similar to the one reported by Diniz \& Bertollo (2006) in the erythrinid Hoplerythrinus unitaeniatus (Spix and Agassiz, 1829) from the São Francisco River Basin. 55

Chromosomal mosaicism was previously reported in H. malabaricus in a fish culture station in Parana Brazil; the authors attribute this fact to possible hybridization events between karyomorphs. ${ }^{56}$ These authors hypothesized that high levels of environmental pollutants might cause this within-individual variation. Maybe this condition of the LM region is a random effect or the result of gene flow between $2 n=20$ and $2 n=42$ karyomorphs, and hybrids between these karyomorphs have been reported in the upper Paraná Basin. ${ }^{14}$

Besides the mostly allopatric condition observed in the Magdalena River, minor karyotypically differences between the UM and the MM suggest the existence of some level of the structure along the river. In South America, H. malabaricus is known for its lentic water preferences, ${ }^{57}$ and the main channel may represent an ecological barrier for dispersal. Congruence between karyotypic and molecular lineages has been demonstrated in southeastern Brazil. ${ }^{9}$ RinconSandoval et al. studied the phylogeography of $H$. malabaricus in NSA and Middle America (Tiura Basin) and found two well-structured lineages (Sp1. and Sp. 2). ${ }^{31} \mathrm{Sp} 1$ includes samples from the Magdalena, Rancheria, Tiura, and Catatumbo River Basins, and Sp2. included samples from the Catatumbo, Atrato, Rancheria, Sinu, San Jorge, and Cauca River Basins. However, the samples from the Magdalena River included in this study $(n=5)$ corresponded to the UM and did not show differentiation along the basin.

Hoplias malabaricus from the Magdalena River encompasses the main karyomorph dichotomy observed elsewhere in the Neotropical region, particularly of their FISH markings and their molecular makeup. A general area cladogram based on 32 fish taxa (including 333 species) consistently point four transAndean basins as the sister clade area for all the remaining South American taxa. ${ }^{58}$

In summary, the $H$. malabaricus from the Magdalena River encompasses the main karyomorph dichotomy observed elsewhere in the Neotropical region, but conspicuously divergent from all other cis-Andean populations in at least some of the FISH markings and the molecular makeup. This dichotomy pattern is probably the result of the vicariant event that resulted from the uplift of the eastern Cordillera of Colombia during the Miocene, which led to the isolation of the current cis- and trans-Andean basins (including the Magdalena River). ${ }^{59,60}$

\section{Acknowledgments}

This research was supported by the Coordenação de Aperfeiçoamento de Pessoal de Nível Superior (CAPES). We are grateful to the Smithsonian Tropical Research Institute (STRI) in Panamá for sharing tissues, and Pedro Caraballo (Universidad de Sucre-Colombia) and Cristhian Conde (Universidade Federal de ViçosaBrazil) for logistic support in the field.

\section{Disclosure Statement}

No competing financial interests exist.

\section{Funding Information}

M.B.C. is supported by FAPESP (2016/22196-2) and CNPQ (304992/2015-1).

\section{References}

1. Oyakawa OT: Family Erythrinidae (Trahiras). In: Check List of the Freshwater Fishes of South and Central América. Reis R, Kullander S, and Ferraris JC (eds), pp. 238240, EDIPUCRS, Porto Alegre, 2003.

2. Abell R, Thieme ML, Revenga C, Bryer M, Kottelat M, Bogutskaya $\mathrm{N}$, et al. Freshwater ecoregions of the world: a 
new map of biogeographic units for freshwater biodiversity conservation. Bioscience 2008;58:403-414.

3. Mattox GMT, Bifi AG, Oyakawa OT. Taxonomic study of Hoplias microlepis (Günther, 1864), a trans-Andean species of trahiras (Ostariophysi: Characiformes: Erythrinidae). Neotrop Ichthyol 2014;12:343-352.

4. Bertollo LAC, Born GG, Dergam JA, Fenocchio AS, Moreira-Filho O. A biodiversity approach in the neotropical Erythrinidae fish, Hoplias malabaricus. Karyotypic survey, geographic distribution of cytotypes and cytotaxonomic considerations. Chromosom Res 2000;8:603-613.

5. Bertollo LAC, Takahashi CS, Moreira-Filho O. Karyotypic studies of two allopatric populations of the genus Hoplias. Rev Bras Genética 1979;II:17-37.

6. da Rosa R, Vicari MR, Dias AL, Giuliano-Caetano L. New insights into the biogeographic and karyotypic evolution of Hoplias malabaricus. Zebrafish 2014;11:198-206.

7. Santos U, Völcker C, Belei F, Cioffi MB, Bertollo LAC. Molecular and karyotypic phylogeography in the Neotropical Hoplias malabaricus (Erythrinidae) fish in eastern Brazil. J Fish Biol 2009;75:2326-2343.

8. Jacobina UP, Paiva E, Dergam JA. Pleistocene karyotypic divergence in Hoplias malabaricus (Bloch, 1794) (Teleostei: Erythrinidae) populations in southeastern Brazil. Neotrop Ichthyol 2011;9:325-333.

9. Pereira TL, Santos U, Schaefer CE, Souza GO, Paiva SR, Malabarba LR, et al. Dispersal and vicariance of Hoplias malabaricus (Bloch, 1794) (Teleostei, Erythrinidae) populations of the Brazilian continental margin. Rocha L (ed). J Biogeogr 2012;40:905-914.

10. Marques D, Santos F, Silva S, Sampaio I, Rodrigues L. Cytogenetic and DNA barcoding reveals high divergence within the trahira, Hoplias malabaricus (Characiformes: Erythrinidae) from the lower Amazon River. Neotrop Ichthyol 2013;11:459-466.

11. Jacobina UP, Lima SMQ, Maia DG, Batalha GSH, Torres RA, Jacobina UP, et al. DNA barcode sheds light on systematics and evolution of neotropical freshwater trahiras. Genetica 2018;146:505-515.

12. Cardoso YP, Rosso JJ, Mabragaña E, González-Castro M, Delpiani M, Avigliano E, et al. A continental-wide molecular approach unraveling mtDNA diversity and geographic distribution of the Neotropical genus Hoplias. PLoS One 2018;13:1-25.

13. Cioffi MB, Bertollo LAC. Initial steps in XY chromosome differentiation in Hoplias malabaricus and the origin of an $\mathrm{X}(1) \mathrm{X}(2) \mathrm{Y}$ sex chromosome system in this fish group. Heredity (Edinb) 2010;105:554-561.

14. Utsunomia R, Pansonato Alves JC, Paiva LRS, Costa Silva GJ, Oliveira C, Bertollo LAC, et al. Genetic differentiation among distinct karyomorphs of the wolf fish Hoplias malabaricus species complex (Characiformes, Erythrinidae) and report of unusual hybridization with natural triploidy. J Fish Biol 2014;85:1682-1692.

15. de Oliveira EA, Sember A, Bertollo LAC, Yano CF, Ezaz $\mathrm{T}$, Moreira-Filho $\mathrm{O}$, et al. Tracking the evolutionary pathway of sex chromosomes among fishes: characterizing the unique XX/XY1Y2 system in Hoplias malabaricus (Teleostei, Characiformes). Chromosoma 2018;127:115-128.

16. Cioffi MB, Molina WF, Moreira-Filho O, Bertollo LAC. Chromosomal distribution of repetitive DNA sequences highlights the independent differentiation of multiple sex chromosomes in two closely related fish species. Cytogenet Genome Res 2011;134:295-302.
17. Albert JS, Petry P, Reis R: Major biogeographic and phylogenetic patterns. In: Historical Biogeography of Neotropical Freshwater Fishes. Albert JS and Reis R (eds), pp. 21-58, University of California Press, Berkeley, Los Angeles, London, 2011.

18. Blanco DR, Lui RL, Bertollo LAC, Margarido VP, Moreira-Filho O. Karyotypic diversity between allopatric populations of the group Hoplias malabaricus (Characiformes: Erythrinidae): Evolutionary and biogeographic considerations. Neotrop Ichthyol 2010;8:361-368.

19. Lopes PA, Alberdi AJ, Dergam JA, Fenocchio AS. Cytotaxonomy of Hoplias malabaricus (Osteichthyes, Erythrinidae) in the Aguapey River (Province of Corrientes, Argentina). Copeia 1998;1998:485.

20. Albert JS, Reis R: Introduction to Neotropical freshwaters. In: Historical Biogeography of Neotropical Freshwater Fishes. Albert JS and Reis RE (eds), pp. 3-19, University of California Press, Berkeley, Los Angeles, London, 2011.

21. Lundberg JG, Marshall LG, Guerrero J, Horton BK, Malabarba MCSL, Wesselingh F: The stage for neotropical fish diversification: a history of tropical South American rivers. Edipucrs. In: Phylogeny and Classification of Neotropical Fishes. Reis R, Vari RP, Lucena ZM, and Lucena CAS (eds), pp. 14-48, Edipucrs, Porto Alegre, 1998.

22. Schaefer S, Albert JS, Reis R: The Andes: riding the tectonic uplift. In: Historical Biogeography of Neotropical Freshwater Fishes. Albert JS and Reis RE (eds), pp. 259279, University of California Press, Berkeley, Los Angeles, London, 2011.

23. Albert JS, Reis RE. Historical Biogeography of Neotropical Freshwather Fishes. Historical Biogeography of Neotropical Freshwater Fishes. University of California Press, Berkeley, Los Angeles, London, 2011.

24. Restrepo JD, Syvitski JP. Assessing the effect of natural controls and land use change on sediment yield in a major Andean river: the Magdalena drainage basin, Colombia. Ambio 2006;35:65-74.

25. DoNascimiento C, Herrera-collazos EE, Herrera-r GA, Ortega-lara A, Villa-navarro FA, Saulo J, et al. Checklist of the freshwater fishes of Colombia: a Darwin Core alternative to the updating problem. Zookeys 2017;708:25-138.

26. Lundberg JG, Chernoff B. A Miocene fossil of the Amazonian fish Arapaima (Teleostei, Arapaimidae) from the Magdalena River Region of Colombia-biogeographic and evolutionary implications. Biotropica 1992;24:2-14.

27. Lundberg JG, Machado-Allison A, Kay RF. Miocene characid fishes from Colombia: evolutionary stasis and extirpation. Science 1986;234:208-209.

28. Galvis G. Peces del Catatumbo. Asociación Cravo Norte, Santa Fe de Bogotá, Colombia, 1997.

29. Maldonado-ocampo JA, Usama-Oviedo JS, Villa-navarro FA, Ortega-lara A, Prada-pedreros S, Jiménez-Segura LF, et al. Peces dulceacuícolas del Chocó biogeografico de Colombia. WWF Colombia. Instituto de Investigación de Recursos Biológicos Alexander von Humbolt (IAvH), Universidad del Tolima. Autoridad Nacional de Acuicultura y Pesca (AUNAP), Pontificia Universidad Javeriana, Bogotá, Colombia, 2012.

30. Maldonado-Ocampo JA, Ortega-lara A, Usma JS, Galvis G, Villa-navarro FA, Vásquez L, et al. Peces de los Andes de Colombia. Instituto de Investigación de Recursos Biologicos Alexander von Humboldt, Bogotá D.C., 2005.

31. Rincon-Sandoval M, Betancur-R R, Maldonado-Ocampo JA. Comparative phylogeography of trans-Andean fresh- 
water fishes based on genome-wide nuclear and mitochondrial markers. Mol Ecol 2019;28:1096-1115.

32. Mancera-Rodríguez NJ, Marquez EJ, Hurtado-Alarcón JC. Uso de citogenética y técnicas moleculares en estudios de diversidad genética en peces colombianos. In: Biología Molecular aplicada a la producción animal y la conservación de especies silvestres. López Herrera A, Ortega-León ÁM, Ortíz-Yusty CE, Márquez EJ, Parra Suescun JE, Zamora-Abrego JG, et al. (eds), pp. 237-312, Editorial Universidad Nacional de Colombia, Bogotá, 2013.

33. Molina WF. An alternative method for mitotic stimulation in fish cytogenetics. Chromosom Sci 2001;5:149-152.

34. Griffiths S. The use of clove oil as an anaesthetic and method for sampling intertidal rockpool fishes. J Fish Biol 2000;57:1453-1464.

35. Oyakawa OT, Mattox G. Revision of the Neotropical trahiras of the Hoplias lacerdae species-group (Ostariophysi: Characiformes: Erythrinidae) with descriptions of two new species. Neotrop Ichthyol. 2009;7:117-140.

36. Bertollo LAC, Cioffi MDB, Moreira-Filho O. Direct chromosome preparations from Freshwater teleost fishes. In: Fish techniques, Ray-Fin Fishes and Chondrichthyans. Ozouf-Costaz C, Pisano E, Foresti F, and de AlmeidaToledo LF (eds), pp. 21-26, CRC Press, Boca Raton, 2015.

37. Levan A, Fredga K, Sandberg A. Nomenclature for centromeric position on chromosomes. Hereditas 1964;52:201-220.

38. Martins C, Ferreira IA, Oliveira C, Foresti F, Galetti PM. A tandemly repetitive centromeric DNA sequence of the fish Hoplias malabaricus (Characiformes: Erythrinidae) is derived from 5S rDNA. Genetica 2006;127:133-141.

39. Cioffi MB, Martins C, Bertollo LAC. Comparative chromosome mapping of repetitive sequences. Implications for genomic evolution in the fish, Hoplias malabaricus. BMC Genet 2009;10:11.

40. Kubat Z, Hobza R, Vyskot B, Kejnovsky E. Microsatellite accumulation on the $\mathrm{Y}$ chromosome in Silene latifolia. Genome 2008;51:350-356.

41. Yano CF, Bertollo LAC, Cioffi MDB. Fish-FISH: Molecular Cytogenetics in Fish Species. Fluorescence in Situ Hybridization (FISH) Application Guide, Springer, Berlin, Heidelberg, 2017, pp. 429-443.

42. Grassi DJ, Swarça AC, Dergam JA, Pastori MC, Fenocchio AS. Cytogenetic characterization of Hoplias malabaricus (Bloch, 1794) from the Ctalamochita River (Córdoba, Argentina): first evidence for southernmost populations of this species complex and comments on its biogeography. Comp Cytogenet 2017;11:15-28.

43. da Rosa R, Giuliano-caetano L, Martins-Santos IC. Differential chromosomal markers between sympatric karyomorphs of the fish Hoplias malabaricus (Bloch, 1794)(Characiformes: Erythrinidae). Comp Cytogenet 2010;4:175-184.

44. Ferreira IA, Bertollo LAC, Martins C. Comparative chromosome mapping of $5 \mathrm{~S}$ rDNA and 5 SHindIII repetitive sequences in Erythrinidae fishes (Characiformes) with emphasis on the Hoplias malabaricus "species complex." Cytogenet Genome Res 2007;118: 78-83.

45. Crombach A, Hogeweg P. Chromosome rearrangements and the evolution of genome structuring and adaptability. Mol Biol Evol 2007;24:1130-1139.

46. Born GG, Bertollo LAC. An XX/XY sex chromosome system in a fish species, Hoplias malabaricus, with a polymorphic NORbearing X chromosome. Chromosom Res 2000;8:111-118.

47. Blanco DR, Lui RL, Bertollo LAC, Diniz D, Moreira-Filho O. Characterization of invasive fish species in a river transposition region: evolutionary chromosome studies in the genus Hoplias (Characiformes, Erythrinidae). Rev Fish Biol Fish 2010;20:1-8.

48. Cioffi MB, Martins C, Centofante L, Jacobina UP, Bertollo LAC. Chromosomal variability among allopatric populations of erythrinidae fish Hoplias malabaricus: mapping of three classes of repetitive DNAs. Cytogenet Genome Res 2009;125:132-141.

49. Vitorino CADA, Souza IL IL, Rosa JNJ, Valente GT, Martins C, Venere PC. Molecular cytogenetics and its contribution to the understanding of the chromosomal diversification in Hoplias malabaricus (Characiformes). J Fish Biol 2011;78:1239-1248.

50. López-Flores I, Garrido-Ramos MA. The repetitive DNA content of eukaryotic genomes. Genome Dyn 2012;7:1-28.

51. Cioffi MB, Kejnovsky E, Bertollo LAC. The chromosomal distribution of microsatellite repeats in the genome of the wolf fish Hoplias malabaricus, focusing on the sex chromosomes. Cytogenet Genome Res 2011;132:289-296.

52. Favarato RM, da Silva M, de Oliveira RR, Artoni RF, Feldberg E, Matoso DA. Cytogenetic diversity and the evolutionary dynamics of rDNA genes and telomeric sequences in the Ancistrus genus (Loricariidae: Ancistrini). Zebrafish 2016;13:103-111.

53. Yano CF, Bertollo LAC, Molina WF, Liehr T, de Bello Cioffi M. Genomic organization of repetitive dnas and its implications for male karyotype and the neo-y chromosome differentiation in Erythrinus erythrinus (Characiformes, Erythrinidae). Comp Cytogenet 2014;8:139-151.

54. de Moraes RLR, Bertollo LAC, Marinho MMF, Yano CF, Hatanaka T, Barby FF, et al. Evolutionary relationships and cytotaxonomy considerations in the genus Pyrrhulina (Characiformes, Lebiasinidae). Zebrafish 2017;14:536-546.

55. Diniz D, Bertollo L a C. Intra- and inter-individual chromosome variation in Hoplerythrinus unitaeniatus (Pisces, Erythrinidae). A population from the Brazilian São Francisco river basin. Genet Mol Biol 2006;29:453-458.

56. Luz-Agostinho K, Agostinho A, Gomes L, Júlio-Jr. H, Fugi R. Effects of flooding regime on the feeding activity and body condition of piscivorous fish in the Upper Paraná River floodplain. Brazilian J Biol 2009;69:481-490.

57. Sant'Anna E, Goitein R. Condition of Hoplias aff. malabaricus (Bloch, 1794) in two coastal streams of Itanhaém river, Brazil. Bol do Inst Pesca 2009;35:429-439.

58. Alber JS, Carvalho T. Neogene assembly of modern faunas. In: Historical Biogeography of Neotropical Freshwater Fishes. 2011;119-136.

59. Hoorn $\mathrm{C}$, et al. Amazonia through time: Andean uplift, climate change, landscape evolution, and biodiversity. Science. 2010;330:927-931.

60. Albert JS, Lovejoy NR, Crampton WGRR. Miocene tectonism and the separation of cis- and trans-Andean river basins: Evidence from Neotropical fishes. J South Am Earth Sci 2006;21:14-27.

Address correspondence to: Nicole Ibagón, PhD

Departamento de Biologia Geral Universidade Federal de Viçosa Avenida P.H. Rolfs, $s / n$

Viçosa 36570-000

Minas Gerais

Brazil

E-mail: nicoleibagon@gmail.com 